\title{
PERBANDINGAN ANTARA PEMBERIAN ANTIBIOTIKA PROFILAKSIS PADA SEKSIO SESAR SESUAI ALUR KLINIS RSUP DR SARDJITO DENGAN ANTIBIOTIKA DOSIS MULTIPEL TERHADAP KEJADIAN INFEKSI LUKA OPERASI
}

\author{
Ardian Rahmansyah, Moh. Hakimi, Rukmono Siswishanto
}

\begin{abstract}
Background: Clinical pathway recommend the use of short-term prophylaxis antibiotics for cesarean section. Long-term antibiotics or multiple doses was found in clinical practice. There are differences in the mode of administration and the number of doses administered at sardjito hospital.

Objective: To determine the effectiveness of short-term antibiotic prophylaxis in cesarean section appropriate to clinical pathway in the prevention of surgical site infection (ssi), the incidence of fever, dysuria events, length of stay.

Method: The study used randomized clinical trial. The study subjects who underwent cesarean section and meet the inclusion and exclusion criteria in the period July 2013 to January 2014 divided into an intervention group $(n=52)$ who received ampicillin 2 gram pre and post-cesarean section, and a control group $(n=54)$ who received ampicillin 2 gram pre cesarean section and 1 gram every 8 hours for 6 times. Observed on days 3 and 10 post-cesarean section. The primary outcomes assessed were the incidence of surgical wound infection based on the criteria of surgical site infection from Centers for Disease Control and Prevention. Secondary outcomes assessed were the incidence of fever, dysuria events, length of stay. Homogeneity analysis were conducted on subject. Outcome analysis performed bivariate with $t$ test and chi squared test.

Results and Discussion : A total of 106 subjects can be analyzed. SSI events in the intervention group at day 3 was $3.8 \%(n=52)$ and control group was $1.84 \%(n=54)$ with $p>0.05$ RR $2.077(95 \% \mathrm{Cl} 0.194$ to 22.219$)$. SSI on day 10 of $7.7 \%(n=52)$ in the intervention group versus $9.3 \%(n=54)$ in controls with $p<0.05 R R$ 0.831 (Cl 95\%, 0.236 to 2.924). Fever events on day 3 by $5.8 \%$ in the intervention group versus $3.7 \%$ in controls with $p>0.05$ RR $1.558(95 \% \mathrm{Cl} 0.271$ to 8.948$)$ and on day 10 was $3.8 \%$ versus $3.7 \%$ with $p>0.05$ RR 1.038 ( $95 \% \mathrm{Cl} 0.152$ to 7.102 ). Dysuria not found on day 3 and but on 10 found $5.8 \%$ in the intervention group versus $11.1 \%$ with $p>0.05$ RR 0.519 (IK95\% 0.137 to 1.968). Length of stay after cesarean section for $3.21 \pm 0.412$ days in the intervention group and $3.26 \pm 0.442$ days in the control group with $p>0.05$ (95\% $\mathrm{Cl}-0.213-0.117)$.

Conclusion: There is no significant difference in the incidence of surgical wound infections, the incidence of fever, dysuria, length of stay between short-term prophylaxis antibiotics ampicillin appropriate to clinical pathway and long-term or multiple doses prophylaxis antibiotics. Short term antibiotics prophylaxis are more efficiently with the same effectiveness in preventing outcomes research.
\end{abstract}

Keywords: prophylaxis antibiotics, ampicillin, short term regimen, long term regimen, cesarean section, surgical site infection.

1. Departemen Obstetri dan Ginekologi Fakultas Kedokteran Universitas Gadjah Mada/

RSUP DR Sardjito, Yogyakarta 


\section{ABSTRAK}

Latar belakang: Alur klinis menganjurkan penggunaan antibiotika profilaksis jangka pendek untuk seksio sesarea. Penggunaan antibiotika jangka panjang atau dosis multipel masih ditemukan. Terdapat perbedaan cara pemberian dan jumlah dosis yang diberikan pada tempat peneliti.

Tujuan: Mengetahui keefektifan antibiotika profilaksis jangka pendek pada seksio sesarea sesuai alur klinis dalam pencegahan infeksi luka operasi (ILO), kejadian demam, kejadian disuria, lama rawat inap,

Metode: Rancangan memakai uji klinik secara random. Subyek penelitian yang menjalani seksio sesarea dan memenuhi kriteria inklusi dan eklusi pada periode Juli 2013 sampai Januari 2014 dibagi menjadi kelompok uji $(n=52)$ yang mendapat ampisilin 2 gram pra dan pasca seksio sesarea, dan kelompok kontrol $(n=54)$ yang mendapat ampisilin 2 gram pra seksio sesarea dan 1 gram tiap 8 jam sebanyak 6 kali. Dilakukan pengamatan pada hari ke 3 dan ke 10 pasca seksio sesarea. Luaran primer yang dinilai adalah kejadian infeksi luka operasi berdasarkan kriteria surgical site infection Center for Disease Control and Prevention. Luaran sekunder yang dinilai adalah kejadian demam, kejadian disuria, lama rawat inap. Dilakukan analisis homogenitas pada subyek. Analisis luaran dilakukan dengan analisis bivariate uji t dan uji $X^{2}$.

Hasil dan pembahasan : Sebanyak 106 subyek dapat dianalisis. Kejadian ILO pada kelompok uji di hari ke 3 sebesar 3,8\% ( $n=52)$ dan kelompok kontrol sebesar 1,84\% ( $n=54)$ dengan $p>0,05$ RR 2,077 (IK 95\% 0,194 - 22,219). Pada hari ke 10 kejadian ILO sebesar 7,7\% ( $n=52)$ pada kelompok uji berbanding 9,3\% ( $n=54)$ pada kontrol dengan $p>0,05$ RR 0,831 (IK 95\%; 0,236 - 2,924). Kejadian demam pada hari ke 3 sebesar $5,8 \%$ pada kelompok uji berbanding 3,7\% pada kontrol dengan p>0,05 RR 1,558 (IK 95\% 0,271-8,948) dan hari ke 10 disuria sebesar 3,8\% berbanding 3,7\% dengan $p>0,05$ RR 1,038 (IK 95\% 0,152-7,102). Tidak ditemukan disuria pada hari ke 3 . Pada hari ke 10 sebanyak 5,8\% pada kelompok uji berbanding $11,1 \%$ dengan $p>0,05$ RR 0,519 (IK95\% 0,137 - 1,968). Lama rawat inap pasca seksio sesarea selama 3,21 $\pm 0,412$ hari pada kelompok uji dan 3,26 $\pm 0,442$ hari pada kelompok kontrol dengan nilai p>0,05 (IK 95\% -0,2130,117).

Kesimpulan: Tidak ada perbedaan bermakna pada kejadian infeksi luka operasi, kejadian demam, kejadian disuria, lama rawat inap antara pemberian antibiotika profilaksis ampisilin jangka pendek sesuai alur klinis dan jangka panjang atau dosis multipel. Cara pemberian antibiotik sesuai alur klinis lebih efisien dengan keefektifan yang sama dalam mencegah luaran penelitian.

Kata kunci: antibiotika profilaksis, jangka pendek, jangka panjang. ampisillin, seksio sesarea, infeksi luka operasi.

\section{PENDAHULUAN}

Faktor risiko yang paling penting pada infeksi maternal pasca partus adalah seksio sesarea. ${ }^{1}$ Komplikasi infeksi yang dapat terjadi setelah operasi seksio sesarea merupakan penyebab morbiditas yang penting dan substansial serta memperlama perawatan di rumah sakit dan menimbulkan biaya kesehatan yang tinggi. ${ }^{2}$

Pasca seksio sesarea dapat terjadi mikroorganisme pada vagina dan endoservik naik menuju tempat operasi, termasuk endometrium, puncak vagina, dan irisan abdomen, yang dapat menyebabkan infeksi. Selain itu tindakan obstetri ginekologi lewat vagina dapat menyebarkan mikroorganisme lewat saluran genital. Infeksi yang terjadi biasanya disebabkan banyak mikroba, seperti streptococcus grup B dan Escheria coli, anaerob Pravatella bivus. Bakteri penyebab bakerial vaginosis seperti Gardnella vaginallis, anaerob, dan mycoplasma juga umum ditemukan pada kultur pasien denngan infeksi post operasi. Mikroorganisme yang umum 
pada kulit seperti stafilokokus epidermidis dan stafilococcus aureus dapat mencapai ke luka operasi melalui irisan kulit. ${ }^{3}$

Penggunaan antibiotika profilaksis pada seksio sesarea sudah dibuktikan mengurangi morbiditas dan mortalitas pasien. Walaupun telah ada bukti klinis yang mendukung cara ini, durasi dan dosis pemberian antibiotika selama ini diberikan dalam berbagai cara yang bervariasi. Pada kenyataan penggunaan dalam praktek klinis masih inkonsisten pada jenis obat, waktu pemberian, durasi pemberian, banyak dosis pemberian oleh karena berbagai variasi dalam setiap komunitas kesehatan. ${ }^{4}$

Hopkins (1998) menyimpulkan dalam penelitiannya bahwa ampisilin dan sefalosporin generasi pertama merupakan obat yang sesuai untuk profilaksis seksio sesarea. Ampsilin untuk suntikan adalah garam monosodium -6-aminophenylacetyl-3,3-dimethyl-7-oxo-4thia-1-azabicyclo heptane-2-carboxylic acid, ini merupakan penisilin sintetis. Ampisilin merupakan agen antibakterial dengan spektrum luas aktivitas bakterisida pada gram positif organisme yang sensitif penicillin dan banyak gram negatif. Ampisilin tersebar pada setiap jaringan dan cairan tubuh dan dieksresikan melalui urin. Penggunaan ampisillin pada kehamilan termasuk kategori B.

Bakteri yang sensitif terhadap ampisilin adalah organisme gram positif: hemolitik dan non hemolitik streptococcus, $D$. pneumoniae, stafilococcus, Clostridia spp., B. anthracis, Listeria monocytogenes, dan Enterokokus; dan organisme gram negatif: $\mathrm{H}$. influenzae, $\mathrm{N}$. gonorrhoeae, $\mathrm{N}$. meningitidis, Proteus mirabilis, dan Salmonella, Shigella, and E. coli. ${ }^{5}$

Mekanisme kerja ampisillin adalah dengan mengikat secara spesifik penicillin binding protein (PBPS) pada sel bakteri. Ampisillin menginhibisi sintesis dinding sel bakteri. Sehingga sel menjadi lisis oleh ensim autolisis sepertiautolisin, selain itu ampisillin juga menghambat autolisin inhibitor. ${ }^{16}$ Ikatan penicillin binding proteins (PBPs) dengan ampisillin dan inhibisi transpeptidase pada proses pembentukan dinding sel akan merusak dinding sel bakteri. ${ }^{5}$

Infeksi luka operasi (ILO) atau surgical site infection (SSI) adalah infeksi pada luka irisan operasi yang terjadi dalam 30 hari pasca operasi dan memiliki paling sedikit salah satu kriteria; 1 ) terdapat cairan pus dari luka, 2) dapat diisolasi organisme dari cairan atau jaringan di luka irisan operasi, 3) terdapat minimal satu tanda atau gejala infeksi (rasa nyeri, nyeri tekan, pembengkakan sekitar luka, kemerahan, rasa panas, luka irisan yang terbuka, dan hasil kultur positif ditemukan kuman), 4) didiagnosis infeksi luka operasi oleh dokter. ${ }^{6,7}$

Penilaian infeksi luka operasi dapat dilakukan sejak hari pertama pasca operasi sampai dengan hari ke tiga puluh pasca operasi. Penilaian ILO pada hari ketiga pasca operasi ataupun sebelum intervensi yg diberikan pada luka operasi bertujuan untuk menilai infeksi yang mungkin ditimbulkan akibat kontaminasi selama operasi dengan inkubasi bakteri dibawah 48 jam. Penilaian juga dapat dilakukan pasca pasien meninggalkan rumah sakit, ataupun pasca luka operasi mendapat intervensi seperti perawatan luka atau terapi tertentu.

Pada clinical pathway / alur klinis operasi seksio sesarea RSUP $\mathrm{Dr}$ Sardjito disebutkan sebelum operasi dilakukan skin test ampisilin injeksi di lengan kanan, diberi label dan dibawakan obat ampisilin 2 gram ke kamar operasi. Ampisilin 2 gram disuntikan intravena di dalam kamar operasi sebelum operasi dimulai. Setelah operasi seksio sesarea jam ke 8 sampai dengan jam ke 12 pasien diberikan suntikan ampisilin 2 gram intravena. Setelah itu tidak perlu diberikan antibiotika per intravena ataupun per oral.

Pada penelitian ini perlakuan yang diberikan dan metode yang digunakan berbeda dengan penelitian-penelitian sebelumnya. Penelitian ini membandingkan pemberian antibiotika profilaksis ampisilin $2 \mathrm{gr}$ sebanyak 2 kali pemberian sebelum dan sesudah operasi, 
dibandingkan dengan pemberian ampisilin $2 \mathrm{gr}$ pre operasi dan dilanjutkan ampisilin 1 gr setiap 8 jam sebanyak 6 kali pemberian.

Penelitian ini bertujuan memberi informasi bermanfaat tentang perbandingan dua macam variasi pemberian antibiotika profilaksis yang digunakan yaitu variasi jangka pendek dan variasi jangka panjang, serta mengetahui keefektifan antibiotika profilaksis jangka pendek atau dosis tunggal pada seksio sesarea dalam pencegahan infeksi pasca operasi dilihat dari infeksi luka operasi, kejadian demam, kejadian disuria, lama rawat inap. Selain itu juga mencari bukti klinis suatu clinical pathway di rumah sakit umum pusat DR. Sardjito Yogyakarta dalam penatalaksanaan pemberian antibiotika profilaksis seksio sesarea.

\section{METODE PENELITIAN}

Metode dengan cara studi acak terkendali. Subyek penelitian dibagi menjadi 2 kelompok yaitu kelompok uji dan kelompok kontrol. Kelompok uji terdiri atas pasien yang mendapatkan antibiotika profilaksis seksio sesarea sesuai alur klinis / clinical pathway RSUP Dr Sardjito yaitu ampisilin 2 gr intravena sebelum seksio sesarea dan diberikan ampisilin 2 gr 12 jam setelah itu. Sedangkan kelompok kontrol terdiri atas pasien yang mendapatkan ampisilin dosis multipel, yaitu ampisilin $2 \mathrm{gr}$ intravena sebelum seksio sesarea dan pasca seksio sesarea diberikan ampisilin 1 gr setiap 8 jam sebanyak 6 kali pemberian atau selama 2 hari pemberian. Luaran yang dinilai dari kedua kelompok adalah ; infeksi luka operasi / surgical site infection pada hari ke 3 dan ke 10 pasca seksio sesarea, kejadian demam pada hari ke 3 dan ke 10 pasca seksio sesarea, kejadian disuria pada hari ke 3 dan ke 10 pasca seksio sesarea, lama rawat inap pasca seksio sesarea.

Populasi penelitian adalah seluruh pasien hamil yang menjalani operasi seksio sesarea RSUP Dr. Sardjito secara elektif ataupun emergensi yang bersedia mengikuti penelitian ini dengan mengeklusikan pasien yang telah mendapatkan antibiotika sebelumnya dalam 24 jam sebelum operasi, ketuban pecah lebih dari atau sama dengan 8 jam, alergi terhadap obat dalam penelitian ini, demam lebih dari sama dengan $38^{\circ} \mathrm{C}$ sebelum operasi, telah ada infeksi pada pasien, kadar hemoglobin di bawah $10 \mathrm{~g} /$ dl, dan diabetes.

Variabel bebas penelitian adalah cara pemberian antibiotika profilaksis seksio sesarea. Sedangkan variabel tergantung adalah infeksi luka operasi, demam, disuria, lama rawat inap pasca seksio sesarea. Adapun variabel luar yang dikendalikan adalah usia pasien, usia kehamilan, paritas, riwayat seksio sesarea, obesitas, indikasi sesarea, jenis operasi.

Hasil penelitian uji statistik dengan menggunakan aplikasi spss. Dilakukan analisis univariat untuk mengetahui karakteristik subyek penelitian dan melihat komparabilitas antar kelompok. Analisis bivariat digunakan untuk mengetahui adanya hubungan antara variabel bebas dengan variabel tergantung. Untuk melihat kebermaknaan perbedaan antara kedua kelompok penelitian pada tiap waktu pengambilan sampel setelah perlakuan dilakukan uji t independen dan uji kei kuadrat. ${ }^{2.3}$ Perbedaan yang bermakna atau signifikan dinilai dari tingkat kemaknaan yang dipakai yakni $p<0,05$.

\section{HASIL}

Dari 106 subyek penelitian yang memenuhi kriteria, dirandomisasi menjadi 52 subyek kelompok uji dan 54 subyek kelompok kontrol selama Juli 2013 sampai dengan Januari 2014. Pada tabel 1 menunjukkan bahwa pada variabel umur pasien tidak terdapat perbedaan yang bermakna, mean umur pasien kelompok uji $29,79 \pm 5,91$ tahun berbanding 29,74 $\pm 5,901$ tahun pada kelompok kontrol, dengan nilai $p=0,967$. Ini berarti umur kedua kelompok homogen secara statistik. Pada variabel paritas, juga didapatkan homogenitas kedua kelompok dengan mean $1,71 \pm 0,915$ berbanding $2,09 \pm 1,12$ dengan nilai $p$ $=0,058$. Body mass index (bmi) kedua kelompok 
juga homogen, dilihat dari mean BMI kelompok uji $26,57 \pm 3,66 \mathrm{~kg} / \mathrm{m}^{2}$ berbanding mean kelompok kontrol $25,61 \pm 3,20 \mathrm{~kg} / \mathrm{m}^{2}$ dengan nilai $p=0,157$. Begitu juga dengan riwayat sc pada subyek menunjukan mean $1,19 \pm 0,10$ versus $1,35 \pm 0,52$ dengan nilai $p=0,080$. Tampak kedua kelompok perlakuan tidak ada perbedaan karakter yang bermakna (homogen). Pada tabel 2 tampak nilai $p=0,640$ pada indikasi seksio sesarea dan nilai $p$ $=0,336$ pada umur kehamilan subyek, sehingga bermakna homogen.

Tabel 1. Uji beda karakter antar kelompok

\begin{tabular}{lccccc}
\hline Variabel & Kelompok & Mean & Std. Deviation & t hitung & $\mathrm{p}$ \\
\hline \multirow{2}{*}{ Umur Pasien } & uji & 29,79 & 5,909 & \multirow{2}{*}{0,042} & 0,967 \\
\multirow{4}{*}{ Paritas } & kontrol & 29,74 & 5,896 & & \\
& uji & 1,71 & 0,915 & & \\
BMI & kontrol & 2,09 & 1,120 & & 0,058 \\
& uji & 26,567 & 3,6640 & \multirow{2}{*}{1,426} & 0,157 \\
\multirow{2}{*}{ Riwayat seksio sesarea } & kontrol & 25,615 & 3,2029 & & \\
& uji & 1,19 & 0,398 & $-1,770$ & 0,080 \\
\hline
\end{tabular}

Tabel 2. Uji beda karakter indikasi seksio sesarea dan umur keh amilan antar kelompok

\begin{tabular}{|c|c|c|c|c|c|}
\hline \multirow{3}{*}{ Variabel } & \multicolumn{4}{|c|}{ Kelompok } & \multirow{3}{*}{$\mathrm{p}$} \\
\hline & \multicolumn{2}{|c|}{ Uji $(n=52)$} & \multicolumn{2}{|c|}{ Kontrol $(n=54)$} & \\
\hline & $\mathrm{n}$ & $\%$ & $\mathrm{n}$ & $\%$ & \\
\hline \multicolumn{6}{|l|}{ Indikasi seksio sesarea } \\
\hline malpresentasi/malposisi & 8 & 50,0 & 8 & 50,0 & \multirow{12}{*}{0,640} \\
\hline disproporsi kepala panggul & 5 & 50,0 & 5 & 50,0 & \\
\hline janin besar & 4 & 80,0 & 1 & 20,0 & \\
\hline Hipertensi & 4 & 66,7 & 2 & 33,3 & \\
\hline riwayat sc & 7 & 31,8 & 15 & 68,2 & \\
\hline induksi gagal & 3 & 50,0 & 3 & 50,3 & \\
\hline stimulasi gagal & 3 & 60,0 & 2 & 40,0 & \\
\hline menolak persalinan vaginal & 4 & 57,1 & 3 & 42,9 & \\
\hline gawat janin & 5 & 38,5 & 8 & 61,5 & \\
\hline plasenta previa & 5 & 45,5 & 6 & 54,5 & \\
\hline Multifetus & 2 & 100,0 & 0 & 0,0 & \\
\hline riwayat infertil/obstetri buruk & 2 & 66,7 & 1 & 33,3 & \\
\hline \multicolumn{6}{|l|}{ Umur kehamilan (minggu) } \\
\hline 29 s.d. 36 & 10 & 66,7 & 5 & 33,3 & \multirow{3}{*}{0,336} \\
\hline 37 s.d. 41 & 41 & 46,1 & 48 & 53,9 & \\
\hline$\geq 42$ & 1 & 50,0 & 1 & 50,0 & \\
\hline
\end{tabular}


Terlihat dari tabel 3 bahwa pada hari ke 3 pasca seksio sesarea subyek kelompok uji yang mendapat antibiotik profilaksis sebanyak dua kali menunjukkan kejadian infeksi luka operasi (ILO) sebesar 3,8\% ( $n=52)$ dan subyek kelompok kontrol yang mendapat antibiotika profilaksis multipel hanya $1,8 \%(n=54)$. Semua kejadian infeksi luka operasi (3 kasus) yang muncul adalah infeksi luka operasi subkutis. Walaupun kejadian ILO lebih besar pada kelompok uji dibandingkan dengan kelompok kontrol, tetapi pada uji kemaknaan tidak didapatkan perbedaan kejadian infeksi luka operasi pada kedua kelompok dengan p 0,614 dan RR 2,077 (IK 95\% 0,194 - 22,219). Terlihat dari tabel 4 bahwa pada hari ke 10 pasca seksio sesarea, kejadian ILO sebesar 7,7\% ditemukan pada subyek kelompok uji dan 9,3\% ditemukan pada subyek kelompok kontrol. Pada uji kemaknaan didapat $\mathrm{p}=1$ dan RR 0,831 (IK $95 \% ; 0,236-2,924)$.

Tabel 3. Hubungan antibiotika profilaksis dan ILO hari ke 3

\begin{tabular}{lcccccccc}
\hline \multirow{2}{*}{ Antibiotika profilaksis } & \multicolumn{5}{c}{ Kejadian ILO hari ke 3} & \multirow{2}{*}{ p } & RR & IK 95\% \\
\cline { 2 - 5 } & \multicolumn{1}{c}{ Ada } & $\%$ & Tidak & $\%$ & & & \\
\hline Uji $(\mathrm{n}=52)$ & 2 & 3,8 & 50 & 96,2 & & 0,614 & 2,077 & $0,194-22,219$ \\
Kontrol $(\mathrm{n}=54)$ & 1 & 1,8 & 53 & 98,2 & & \\
\hline
\end{tabular}

Tabel 4. Hubungan antibiotika profilaksis dan ILO hari ke 10

\begin{tabular}{lcccccccc}
\hline \multirow{2}{*}{ Antibiotika profilaksis } & \multicolumn{5}{c}{ Kejadian ILO hari ke 10} & \multirow{2}{*}{ R } & RR & IK 95\% \\
\cline { 2 - 5 } & & Ada & $\%$ & Tidak & $\%$ & & & \\
\hline Uji $(n=52)$ & 4 & 7,7 & 48 & 92,3 & \multirow{2}{*}{1,000} & 0,831 & $0,236-2,924$ \\
Kontrol $(n=54)$ & 5 & 9,3 & 49 & 90,7 & & \\
\hline
\end{tabular}

Kejadian demam pada hari ke 3 pasca seksio sesarea muncul sebesar 5,8\% pada kelompok uji ( $n=52)$ dan 3,7\% pada kelompok kontrol $(n=54)$. Semua kejadian demam dinilai pada suhu axila diatas 380C. Terlihat kejadian demam lebih besar pada kelompok uji dibandingkan dengan kelompok antibiotika kontrol secara proporsi, tetapi pada uji kemaknaan tidak didapatkan perbedaan kejadian infeksi luka operasi pada kedua kelompok dengan p 0,675 dan RR 1,558 (IK $95 \%$ 0,271-8,948). Kejadian demam pada hari ke 10 pasca seksio sesarea pada kedua kelompok sama. Kejadian demam muncul sebesar 3,8\% pada kelompok uji ( $n=52)$ dan $3,7 \%$ pada kelompok lawannya $(n=54)$. Terlihat perbedaan kejadian demam secara proporsi jumlahnya kecil sekali pada kedua kelompok, begitu juga pada uji kemaknaan tidak didapatkan perbedaan bermakna kejadian infeksi luka operasi pada kedua kelompok dengan $\mathrm{p}=1$ dan RR mendekati angka 1 yaitu 1,038 (IK 95\% 0,152-7,102). 
Tabel 5. Hubungan antibiotika profilaksis dan kejadian demam hari ke 3

\begin{tabular}{lcccccccc}
\hline \multirow{2}{*}{ Antibiotika profilaksis } & \multicolumn{5}{c}{ Kejadian demam hari ke 3} & \multirow{2}{*}{ p } & RR & IK 95\% \\
\cline { 2 - 5 } & Ada & $\%$ & Tidak & $\%$ & & & & \\
\hline Uji $(n=52)$ & 3 & 5,8 & 49 & 94,2 & & 0,675 & 1,558 & $0,271-8,948$ \\
Kontrol $(n=54)$ & 2 & 3,7 & 52 & 96,3 & & & \\
\hline
\end{tabular}

Tabel 6. Hubungan antibiotika profilaksis dan kejadian demam hari ke 10

\begin{tabular}{|c|c|c|c|c|c|c|c|}
\hline \multirow{2}{*}{ Antibiotika profilaksis } & \multicolumn{4}{|c|}{ Kejadian demam hari ke 10} & \multirow{2}{*}{$\mathrm{p}$} & \multirow{2}{*}{$\mathrm{RR}$} & \multirow{2}{*}{ IK 95\% } \\
\hline & Ada & $\%$ & Tidak & $\%$ & & & \\
\hline Uji $(n=52)$ & 2 & 3,8 & 50 & 96,2 & \multirow{2}{*}{1,000} & \multirow{2}{*}{1,038} & \multirow{2}{*}{$0,152-7,102$} \\
\hline Kontrol $(n=54)$ & 2 & 3,7 & 52 & 96,3 & & & \\
\hline
\end{tabular}

Pada kedua kelompok perlakuan tidak ditemukan adanya subyek yang mengalami disuria pada hari ke 3 pasca seksio sesarea. Pada tabel 7 ditampilkan kejadian disuria pada hari ke 10 pasca seksio sesarea sebesar 5,8\% pada kelompok uji $(n=52)$ dan
$11,1 \%$ pada kelompok kontrol. Kedua kelompok menunjukkan tidak ada perbedaan bermakna pada kejadian disuria pada hari ke 10 pasca seksio sesarea dengan nilai p 0,489 dan RR 0,519 (IK95\% $0,137-1,968)$.

Tabel 7. Hubungan antibiotika profilaksis dan kejadian disuria hari ke 10

\begin{tabular}{|c|c|c|c|c|c|c|c|}
\hline \multirow{2}{*}{ Antibiotika profilaksis } & \multicolumn{4}{|c|}{ Kejadian disuria hari ke 10} & \multirow{2}{*}{$\mathrm{p}$} & \multirow{2}{*}{$\mathrm{RR}$} & \multirow{2}{*}{ IK 95\% } \\
\hline & Ada & $\%$ & Tidak & $\%$ & & & \\
\hline Uji $(n=52)$ & 3 & 5,8 & 49 & 94,2 & \multirow{2}{*}{0,489} & \multirow{2}{*}{0,519} & \multirow{2}{*}{$0,137-1,968$} \\
\hline Kontrol $(n=54)$ & 6 & 11,1 & 48 & 88,9 & & & \\
\hline
\end{tabular}

Pada tabel 8 ditampilkan perbandingan mean lama rawat inap pasca seksio sesarea kedua kelompok tampak mean 3,21 $\pm 0,412$ hari pada yang mendapat antibiotika profilaksis di kelompok uji dan 3,26 $\pm 0,442$ hari pada yang mendapat antibiotika multipel di kelompok kontrol. Perbedaan 0,05 hari tentu tidak bermakna secara klinis dan statistik dengan nilai p 0,567 (IK 95\% -0,213-0,117).

Tabel 8. Hubungan antibiotika profilaksis dengan lama rawat inap

\begin{tabular}{|c|c|c|c|c|c|c|}
\hline Variabel & $\begin{array}{l}\text { Antibiotika } \\
\text { profilaksis }\end{array}$ & $\begin{array}{l}\text { Mean } \\
\text { (hari) }\end{array}$ & Std. Deviation & t hitung & $p$ & IK 95\% \\
\hline \multirow{2}{*}{ Lama rawat inap } & Uji $(n=52)$ & 3,21 & 0,412 & \multirow{2}{*}{0,574} & \multirow{2}{*}{0,567} & \multirow{2}{*}{$\begin{array}{c}-0,213- \\
0,117\end{array}$} \\
\hline & Kontrol $(n=54)$ & 3,26 & 0,442 & & & \\
\hline
\end{tabular}




\section{PEMBAHASAN}

Pada penelitian ini tidak didapatkan perbedaan karakteristik kedua kelompok perlakuan atau bisa disebut homogen. Karakteristik subyek penelitian dilihat berdasarkan umur subyek, paritas, bmi, riwayat seksio sesarea, umur kehamilan, indikasi seksio sesarea. Perbedaan mean pada semua karakter subyek tidak bermakna secara klinis. Secara statistik juga tidak ada perbedaan bermakna antara kelompok perlakuan $(p>0,05)$. Penilaian hasil perlakuan dilakukan dua kali yaitu pada hari ke 3 dan ke 10 pasca seksio sesarea. Dilakukan analisis secara per protokol. Ternyata luaran primer penelitian ini menunjukkan bahwa cara pemberian antibiotika profilaksis berupa ampisilin 2 gram pra dan pasca seksio sesarea tidak menurunkan kejadian infeksi luka operasi. Pada hari ke 10 didapatkan kejadian ILO 7,7\% pada kelompok uji dan 9,3\% pada kelompok kontrol dengan $p$ $>0,05$ RR 0,831 (IK 95\%; 0,236-2,924). Pada hari ke 10 kejadian pada kelompok uji lebih sedikit, ini berbeda dengan hari ke 3 . Ada kemungkinan subyek meminum antibiotika lainnya selama rawat jalan. Kurangnya pengawasan pada subyek setelah dipulangkan dari rumah sakit juga mempengaruhi hasil ini. Penelitian serupa dengan jenis antibiotika yang berbeda pernah dilakukan Kausar (2010) membandingkan cara pemberian siklus pendek (jumlah lebih sedikit) dan cara pemberian siklus panjang (jumlah multipel) dengan total 200 subyek, didapatkan hasil kejadian infeksi luka operasi $12 \%$ pada cara siklus pendek dan $15 \%$ pada cara siklus panjang dengan $p>0,05$ yang diinterpretasikan tidak ada perbedaan bermakna pada kejadian infeksi luka operasi. $^{8}$

Luaran sekunder penelitian ini menunjukkan bahwa kejadian demam pada hari ke 3 $(p>0,05)$ dan hari ke $10(p>0,05)$ subyek yang mendapat antibiotika profilaksis siklus pendek tidak berbeda bermakna dengan subyek yang mendapat antibiotika profilaksis siklus panjang atau multipel. Kejadian disuria pada hari ke 3 tidak dapat dianalisis nilai $p$ nya karena, tidak ditemukan morbiditas disuria pada hari ke 3 pasca seksio sesarea pada subyek. Pada hari ke 10 pasca seksio sesarea, kejadian disuria lebih kecil pada kelompok uji, dan tidak ada perbedaan secara statistik. Semakin lama hari rawat inap maka akan semakin rendah biaya yang dikeluarkan. Dari penelitian ini didapatkan lama rawat inap pasca seksio sesarea pada subyek yang mendapat antibiotika profilaksis jangka pendek sebesar $3,21 \pm 0,412$, berbeda tipis lebih cepat daripada subyek yang mendapat antibiotika cara panjang sebesar $3,26 \pm 0,442$, namun tak bermakna $p>0,05$. Bisa diasumsikan bahwa karena tidak ada perbedaan kejadian infeksi luka operasi maka tidak ditemukan juga perbedaan lama rawat inap pasca seksio sesarea.

Kekuatan penelitian untuk kelompok uji dan kontrol pada kejadian infeksi luka operasi sebesar 60\%. Dengan kekuatan sebesar itu menyebabkan potensi bias pada penelitian ini. Faktor yang mempengaruhi penurunan kekuatan penelitian adalah penyeleksian subyek, tidak adanya penyamaran perlakuan penelitian, dan variabel luar. Namun demikian, secara statistik dinyatakannya tidak ada perbedaan kemaknaan kejadiaan infeksi luka operasi pada kedua kelompok penelitian atau dinyatakan kedua perlakuan antibiotika sama efektif sebagai profilaksis dalam pencegahan kejadian infeksi luka operasi.

\section{KESIMPULAN}

Pemberian antibiotika profilaksis ampisilin 2 gram sebanyak dua kali pemberian atau disebut cara jangka pendek, tidak berbeda bermakna dengan pemberian ampisilin 2 gram pra operasi dan 1 gram sebanyak enam kali pasca operasi atau disebut cara jangka panjang atau dosis multipel, dilihat dari kejadian infeksi luka operasi, kejadian demam, kejadian disuria dan lama rawat inap. Semakin sedikit tindakan invasif berupa 
pemberian injeksi yang dilakukan diharapkan mengurangi ketidaknyamanan pasien, bahkan mengurangi biaya yang dikeluarkan untuk penyediaan antibiotika. Hal ini sangat sesuai dilaksanakan pada situasi dengan keterbatasan sumber daya.

Dengan cara yang lebih pendek dan antibiotika lebih sedikit maka lebih efisien secara ekonomi dengan tetap mencapai efektifitas yang sama dalam mencegah kejadian infeksi luka operasi. Hasil penelitian ini dapat menjadi bukti klinis lokal sebagai dasar penggunaan antibiotika profilaksis yang lebih rasional dan efisien.

\section{SARAN}

Pemberian antibiotika profilaksis seksio sesarea menjadi prosedur tetap yang dilakukan untuk mengurangi kejadian infeksi luka operasi. Pemberian antibiotika profilaksis dapat dilakukan lebih efisien tanpa mengurangi kefektifannya dalam mencegah infeksi luka operasi. Penggunaan ampisilin dalam jangka pendek dapat diterapkan sebagai antibiotika profilaksis seksio sesarea.

\section{DAFTAR PUSTAKA}

1. Hopkins L, Smaill FM. 2010. Antibiotic prophylaxis regimens and drugs for cesarean section (Review). Cochrane Database Of Systematic Reviews.

2. Handerson E. 1995. Incidence of Hospital AcquiredInfections Associated with Caesarean Section. J Hasp Infect. 29:245-255.

3. Soper D. 2009. Prevention of Surgical Site Infection. Infectious Disease in Obstetric and Gynecology a Systematic Approach Management. ACOG. www. acog.org

4. Opoku BK. 2007. Prophylactic Antibiotic During Caesarean Sections At Komfo Anokye Teaching Hospital, Kumasi. Ghana Medical Journal; Volume 41: 48-51.

5. Petri, W.A. 2006. Penicillins, Chepalosporins, And Other Beta Lactam Antibiotics. Goodman and Gilman The Pharmacological Basis of Therapeutics. 11 edition. 44:1127-1154
6. Rubin RH. 2006. Surgical wound infection: epidemiology, pathogenesis, diagnosis and management. BMC Infectious Disease. BMC Infectious Diseases 2006, 6 : $171 \mathrm{http}: / / \mathrm{www}$. biomedcentral.com/ 1471-2334/6/171

7. Surgical Site Infection (SSI) Event. CDC's Guideline for Prevention of Surgical Site Infection 1999. http://www.cdc.gov/nhsn/PDFs/ pscManual/ 9pscSSIcurrent.pdf

8. Dahlan MS. 2008. Langkah-Langkah Membuat Proposal Penelitian Bidang Kedokteran dan Kesehatan. Jakarta: Sagung Seto.

9. Dahlan MS. 2009. Besar sampel dan cara pengambilan sampel dalam penelitian kedokteran dan kesehatan. Edisi 3. Jakarta: Salemba Medika.

10. Bayles, K.W. 2000. The bactericidal action of penicillin: New clues to an unsolved mystery. Trends Microbiol. 8:81274-81278

11. Garner JS. 1985. Supercedes guideline for prevention of surgical wound infections. CDC guideline for prevention of surgical wound infection. Revised 1995. Infect Control 1986;7(3):193-200.

12. Gibbs RS. 1980. Clinical risk factors for puerperal infection. Obstet Gynaecol; 55: 1785-1835.

13. Kausar R, Yasmeen L. 2010. Elective caesarean section; short antibiotic prophylaxis versus prolonged antibiotic therapy. Professional Med J Jun 2010;17(2):304-307.

14. Mangram AJ, Horan TC, Pearson ML, Silver LC, Jarvis WR. 1999. Guideline for Prevention of Surgical Site Infection. The Hospital Infection Control Practices Advisory Committee. AJIC: American Journal of Infection Control. volume 27:97-134

15. Mitt P, Lang K, Peri A, Meimets M. 2005. Surgical site infection during cesarean section in Estonian university hospital: post discharge surveylance and analysis of risk factors. Infection Control and Hospital Epidemilogy volume 26:449-454.

16. Schalkwyk J, Van Eyk N. 2010. Antibiotic Prophylaxis In Obstetric Procedures volume 247. SOGC Clinical Practice Guideline. Society of Obstetricians and Gynaecologists of Canada. http://sogc.org/wpcontent/uploads/2013/01/gui247CPG1009E_000. pdf

17. Shakya A. 2010. Comparison of single versus multiple doses of antibiotic prophylaxis in reducing post-elective Caesarean section infectious morbidity. Kathmandu Univ Med J (KUMJ). Apr-Jun; 8(30):179-84 